Prepared in cooperation with the National Park Service

\title{
Discharge and Dissolved-Solids Characteristics and Trends of Snake River above Jackson Lake at Flagg Ranch, Wyoming, 1986-2018
}
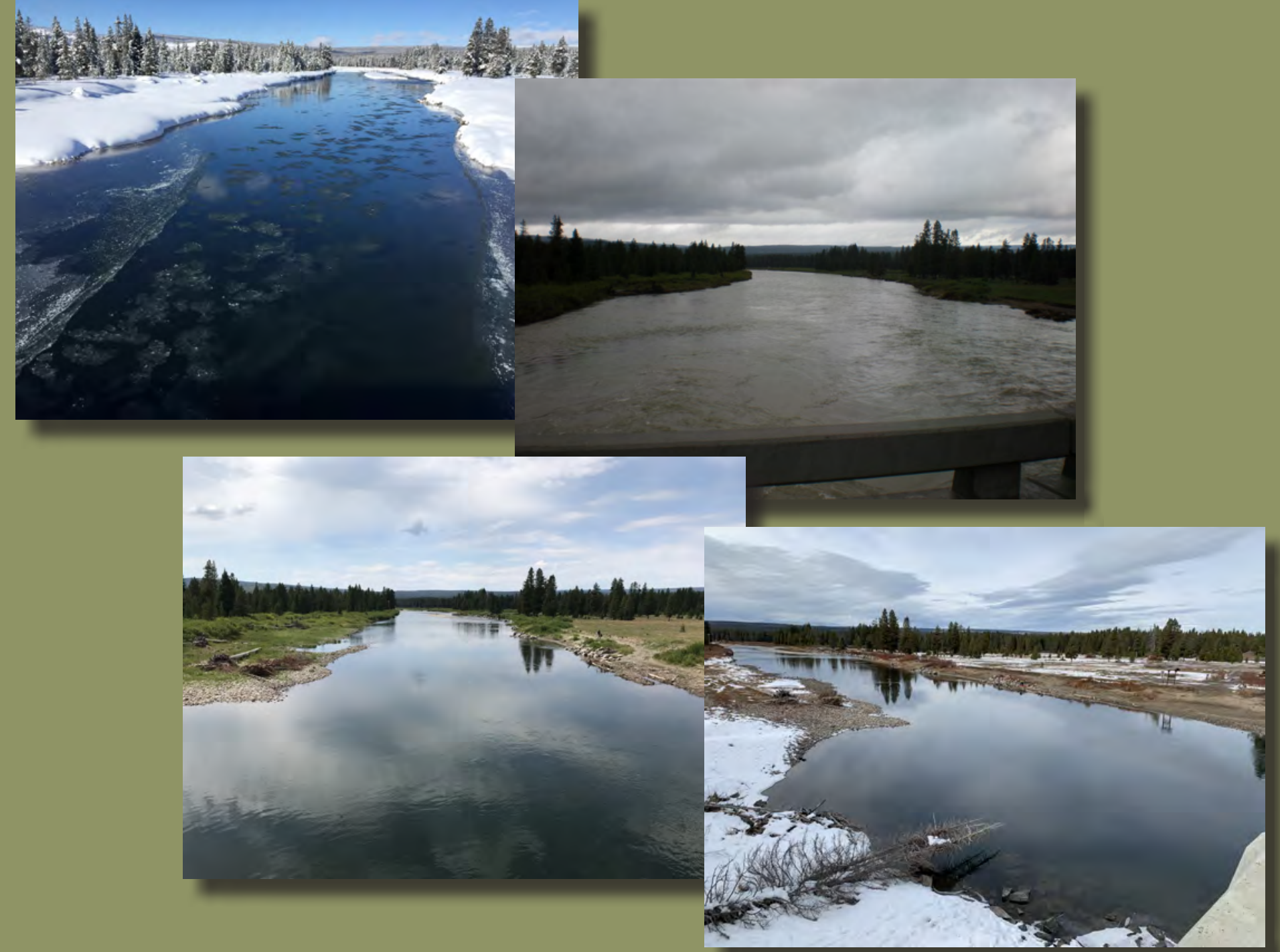

Scientific Investigations Report 2020-5062

U.S. Department of the Interior

U.S. Geological Survey 
Cover Photos: Snake River above Jackson Lake at Flagg Ranch streamgage.

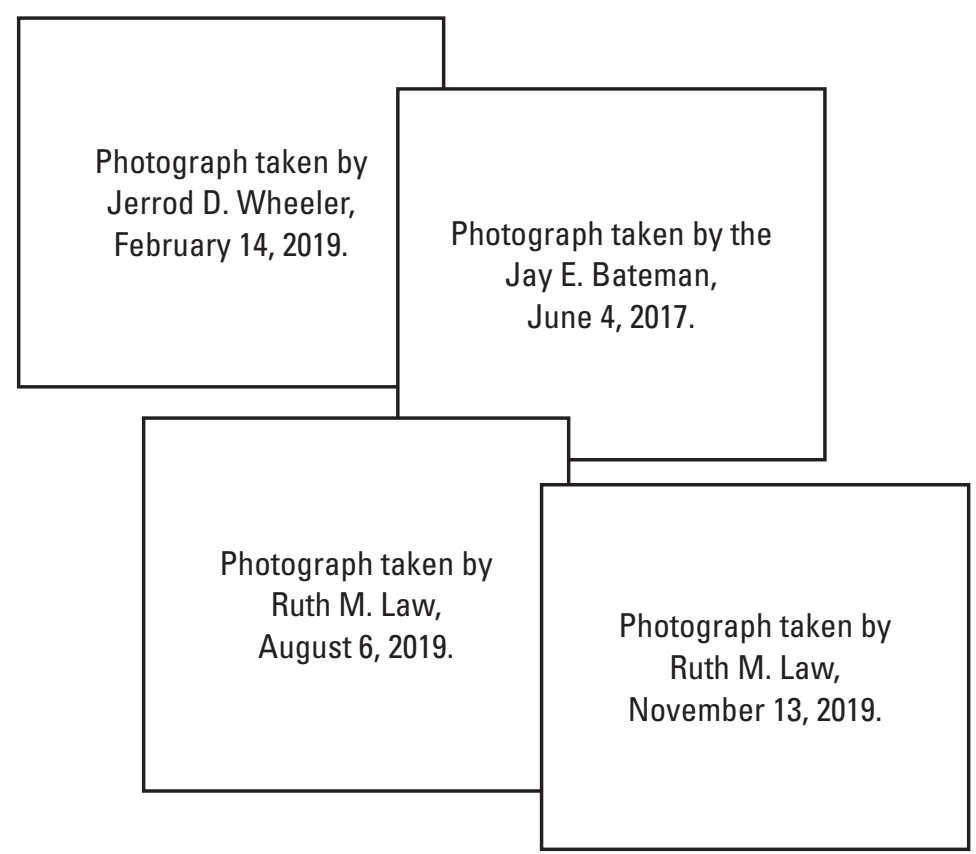




\section{Discharge and Dissolved-Solids \\ Characteristics and Trends of Snake River above Jackson Lake at Flagg Ranch, Wyoming, 1986-2018}

By Olivia L. Miller and Cheryl A. Eddy-Miller

Prepared in cooperation with the National Park Service

Scientific Investigations Report 2020-5062 


\title{
U.S. Department of the Interior \\ DAVID BERNHARDT, Secretary
}

\author{
U.S. Geological Survey \\ James F. Reilly II, Director
}

U.S. Geological Survey, Reston, Virginia: 2020

For more information on the USGS - the Federal source for science about the Earth, its natural and living resources, natural hazards, and the environment—visit https://www.usgs.gov or call 1-888-ASK-USGS.

For an overview of USGS information products, including maps, imagery, and publications, visit https://store.usgs.gov/.

Any use of trade, firm, or product names is for descriptive purposes only and does not imply endorsement by the U.S. Government.

Although this information product, for the most part, is in the public domain, it also may contain copyrighted materials as noted in the text. Permission to reproduce copyrighted items must be secured from the copyright owner.

Suggested citation:

Miller, O.L., and Eddy-Miller, C.A., 2020, Discharge and dissolved-solids characteristics and trends of Snake River above Jackson Lake at Flagg Ranch, Wyoming, 1986-2018: U.S. Geological Survey Scientific Investigations Report 2020-5062, 19 p., https://doi.org/10.3133/sir20205062.

ISSN 2328-0328 (online) 


\section{Acknowledgments}

The authors gratefully acknowledge Andrew Ray, National Park Service, who assisted with the processing of data collected by that agency.

The authors also acknowledge the insightful reviews of the document by Tom Marston, Jason Alexander, and Kendall Fitzgerald, U.S. Geological Survey. 



\section{Contents}

Acknowledgments ……...................................................................................................................

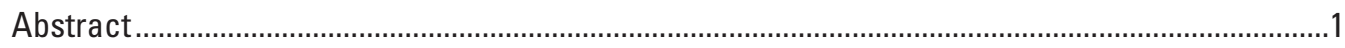

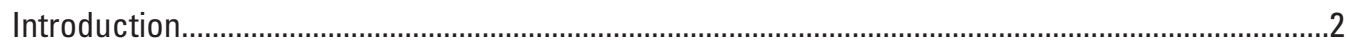

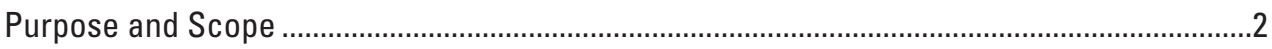

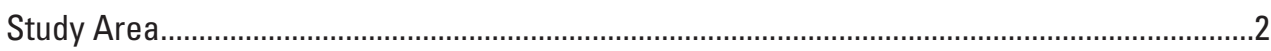

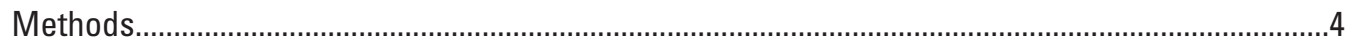

Discharge, Specific Conductance, and Dissolved-Solids Characteristics .....................................5

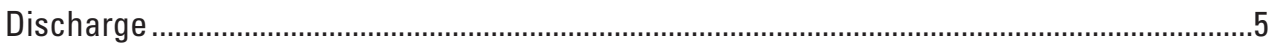

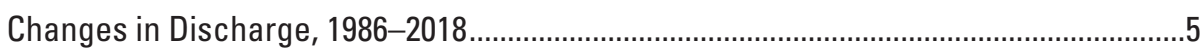

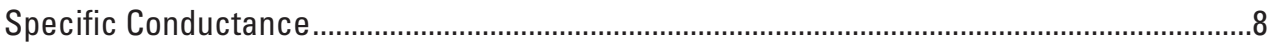

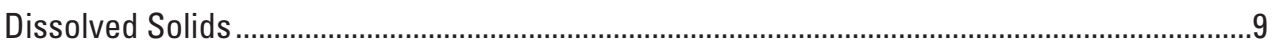

Dissolved-Solids Characteristics ................................................................................

Dissolved-Solids Trends, 1986-2018 ..............................................................................13

Dissolved-Solids Sampling Frequency and the Potential Effects on Data Analysis ...............17

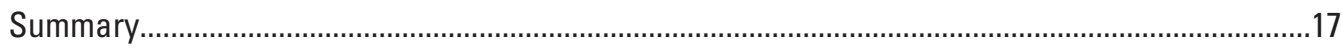

References Cited..................................................................................................................

\section{Figures}

1. Map showing location and drainage area of U.S. Geological Survey streamgage 13010065, Snake River above Jackson Lake at Flagg Ranch.........................3

2. Graph showing daily mean discharge at Snake River above Jackson Lake at Flagg Ranch, October 1983-December 2018....................................................................

3. Graph showing mean of daily mean discharge, Snake River above Jackson Lake at Flagg Ranch, 1983-2018 ......................................................................................7

4. Plot showing discharge characteristics of Snake River above Jackson Lake at Flagg Ranch streamgage, January 1986-December 2018 ................................................8

5. Plot showing measurement of specific conductance at Snake River above Jackson Lake at Flagg Ranch streamgage ................................................................

6. Graph showing number of water-quality samples collected over time by season at Snake River above Jackson Lake at Flagg Ranch .....................................................10

7. Graph showing dissolved-solids concentration over time identified by season at Snake River above Jackson Lake at Flagg Ranch ......................................................11

8. Boxplot showing dissolved-solids concentration distribution by season at Snake River above Jackson Lake at Flagg Ranch

9. Graph showing total dissolved-solids concentration compared to discharge by season at Snake River above Jackson Lake at Flagg Ranch...

10. Plot showing results of Weighted Regressions on Time, Discharge, and Season model analyses at Snake River above Jackson Lake at Flagg Ranch.

11. Graph showing estimated total dissolved-solids over time at Snake River above Jackson Lake at Flagg Ranch.

12. Graphs showing modeled concentration-discharge relationship over time at Snake River above Jackson Lake at Flagg Ranch 


\title{
Tables
}

1. Stream properties and chemical constituents for which water samples were analyzed at the U.S. Geological Survey Snake River above Jackson Lake at Flagg Ranch streamgage (13010065)

\section{Conversion Factors}

International System of Units to U.S. customary units

\begin{tabular}{|c|c|c|}
\hline Multiply & By & To obtain \\
\hline \multicolumn{3}{|c|}{ Length } \\
\hline meter $(\mathrm{m})$ & 3.2808 & feet $(\mathrm{ft})$ \\
\hline \multicolumn{3}{|c|}{ Area } \\
\hline square kilometer $\left(\mathrm{km}^{2}\right)$ & 0.3861 & square mile $\left(\mathrm{mi}^{2}\right)$ \\
\hline \multicolumn{3}{|c|}{ Mass } \\
\hline kilogram (kg) & 2.205 & pound avoirdupois (lb) \\
\hline \multicolumn{3}{|c|}{ Flow rate } \\
\hline cubic meter per second $\left(\mathrm{m}^{3} / \mathrm{s}\right)$ & 35.31 & cubic foot per second $(\mathrm{ft} 3 / \mathrm{s})$ \\
\hline
\end{tabular}

Temperature in degrees Celsius $\left({ }^{\circ} \mathrm{C}\right)$ may be converted to degrees Fahrenheit ( $\left.{ }^{\circ} \mathrm{F}\right)$ as follows:

$$
{ }^{\circ} \mathrm{F}=\left(1.8 \times{ }^{\circ} \mathrm{C}\right)+32 .
$$

\section{Datum}

Vertical coordinate information is referenced to the National Geodetic Vertical Datum of 1929 (NGVD 29).

Horizontal coordinate information is referenced to the North American Datum of 1983 (NAD 83).

Altitude, as used in this report, refers to distance above the vertical datum.

\section{Supplemental Information}

Concentrations of chemical constituents in water are given in milligrams per liter (mg/L). Specific conductance is given in microsiemens per centimeter at 25 degrees Celsius $(\mu \mathrm{S} / \mathrm{cm}$ at $25^{\circ} \mathrm{C}$ ).

\section{Abbreviations}

\author{
IQR interquartile range \\ NPS National Park Service \\ USGS U.S. Geological Survey \\ WRTDS Weighted Regressions on Time, Discharge, and Season
}




\title{
Discharge and Dissolved-Solids Characteristics and Trends of Snake River above Jackson Lake at Flagg Ranch, Wyoming, 1986-2018
}

\author{
By Olivia L. Miller and Cheryl A. Eddy-Miller
}

\section{Abstract}

The headwaters of the Snake River are in the mountains of northwestern Wyoming. Maintaining the recognized high quality of water in Grand Teton National Park is a National Park Service (NPS) priority. To characterize and understand the water resources of Grand Teton National Park, the NPS established a monitoring program to monitor the quality of area surface waters. Beginning in 2006, water was sampled by the NPS and analyzed for a range of chemical species at the Snake River above Jackson Lake at Flagg Ranch streamgage 13010065 (hereafter referred to as "Snake River at Flagg Ranch"), a site where the U.S. Geological Survey (USGS) previously sampled and analyzed water from 1986 through 2004. The USGS, in cooperation with the NPS, evaluated water-quality data collected by both entities to determine if discharge and total dissolved solids (referred to as dissolved solids) have changed in the Snake River at the Flagg Ranch.

To understand potential changes with time in dissolved solids, discharge was analyzed between January 1986 and December 2018, which corresponds with the time period when water-quality data were collected. Mean annual discharge varied during this time, with high, low, mean, and median flows generally increasing from 1986 through 1998, decreasing through 2005, and then generally increasing through 2018.

Combining water-quality data collected by the USGS and NPS provides a longer, more complete dataset for analyses. During the period of time when NPS was the sampling agency, specific conductance data were collected, but dissolved-solids data were not. The specific conductance data from both agencies were evaluated to determine if combining the data was justified. The interquartile ranges of data collected by both agencies are similar, and rapid, large changes in values during the period of transition between USGS and NPS sampling do not occur. The USGS and NPS datasets are not statistically different in the spring, summer, or fall, but are statistically different in the winter. The winter differences could be a function of the lack of wintertime NPS sampling, which excludes higher-concentration, lower-discharge data or a function of changes in the actual concentration in the stream. Although there is some difference in the winter datasets, the similarity in sampling methods and general overall data characteristics justifies combining the data for trend analyses.

Because the dissolved-solids parameter is useful for managers, it is often calculated from specific conductance using a linear regression model when dissolved-solids data are absent. For this study, creating a modeled dataset of dissolved solids for the NPS data collection period of time provided a longer, more complete dataset of dissolved-solids concentrations.

The concentrations of dissolved solids over time are identified by season and indicate that samples collected in the fall and winter have higher concentrations than samples collected in spring and summer. Specifically, the mean dissolved-solids concentrations in fall and winter are around 188 milligrams per liter $(\mathrm{mg} / \mathrm{L})$, whereas the mean concentrations are around $130 \mathrm{mg} / \mathrm{L}$ in spring and summer. This difference is generally attributed to the dilution of spring and summer samples by snowmelt generated runoff during the high-flow period of the year.

Trend analyses of dissolved-solids concentrations and loads indicate that an upward trend in concentration from 1986 to 2018 is likely, and a downward trend in load is highly likely. Comparing 1986 to 2018, dissolved-solids concentration is estimated to have increased by $2.25 \mathrm{mg} / \mathrm{L}$ (1.4 percent). During that same period, the dissolved-solids load is estimated to have decreased 11.8 million kilograms per year (12-percent decrease). This decrease is consistent with the estimated decrease in annual mean of daily mean discharge. Because 10 percent of the total change in dissolved-solids load is related to a change in the concentration-discharge relationship and 2 percent is related to changes in discharge, the decreased load is related less to changes in discharge and more to landscape scale processes that are affecting the concentration-discharge relationship. 
As noted above, the data collected by the USGS and NPS are generally comparable with regards to sampling and analytical methods, and data collected by both agencies were used as one dataset for trend analyses. The current NPS sampling schedule, however, is creating a dataset biased towards lower concentration dissolved-solids data, which occurs during higher summer flows, by only sampling during April through November. From 1986 to 2018, the percentage of NPS samples is small enough that the effect on trends is expected to be minimal. Because of the importance of low flow (winter season) data, it is likely that an April through November sampling regime may affect the ability to detect trends or determine seasonality in the future. Collection of winter data in particular is important based on the findings that the changes in the modeled concentration-discharge relationship over time have been most pronounced during the winter (represented by February) months.

\section{Introduction}

The headwaters of the Snake River are in the mountains of northwestern Wyoming, and this region is primarily on lands administered by the National Park Service (NPS) and the Bridger-Teton National Forest (fig. 1). The surface waters of Grand Teton National Park are classified as Outstanding or Class 1 waters (Wyoming Department of Environmental Quality, 2013), and are recognized as an important resource by the NPS. Maintaining this quality of water is a priority of the NPS (Levandowski and others, 2017). All natural waters contain some dissolved solids, and the concentration is a function of contact with rocks, soils, and other materials; and discharge. Specific conductance and total dissolved solids (referred to as dissolved solids) are often used as a general indicator of stream water quality.

The NPS established a water-resources monitoring program to characterize the water quality of the Snake River and alpine lakes in Grand Teton National Park and John D. Rockefeller Jr. Memorial Parkway (Levandowski and others, 2017). As part of that program, the NPS began sampling the Snake River above Jackson Lake at Flagg Ranch, streamgage 13010065 (hereafter referred to as "Snake River at Flagg Ranch") in 2006, a site where the U.S. Geological Survey (USGS) sampled water quality from 1986 through 2004. Recent data from NPS and published historical data from the USGS can be used to help describe and define the water quality of the Snake River headwaters. To better understand the overall water-quality characteristics of the Snake River and determine if changes are occurring over time, the USGS, in cooperation with the NPS, evaluated and used the data from both agencies to analyze discharge, specific conductance, and dissolved-solids concentrations at the Snake River at Flagg Ranch.

\section{Purpose and Scope}

The purpose of this report is to describe streamflow and water-quality data collected by the USGS and the NPS during 1986-2018 at the Snake River at Flagg Ranch. Specifically, this report describes (1) the analysis of available data collected by both agencies and the validity of combining them into one dataset; (2) a general characterization of discharge, specific conductance, and dissolved-solids concentrations, and changes (trends) in discharge and dissolved solids during 1986-2018; and (3) the potential effects of different water-quality sampling frequencies. Many water-quality constituents have been collected at this site; however, the scope of this study and report is limited to discharge, specific conductance, and dissolved solids.

\section{Study Area}

The Snake River originates in southern Yellowstone National Park and flows southward before entering John D. Rockefeller Jr. Memorial Parkway and Grand Teton National Park (fig. 1). The study area is the 1,259 square kilometers $\left(\mathrm{km}^{2}\right)$ of the drainage area upstream from the Snake River at Flagg Ranch (fig. 1, streamgage 13010065) that drains primarily mountainous, forested lands. The elevation ranges from 2,073 meters (m) above the National Geodetic Vertical Datum of 1929 at the streamgage to 3,142 m above National Geodetic Vertical Datum of 1929 at the summit of Mount Sheridan. The study area is characterized by cold winters and warm summers, with monthly maximum temperatures ranging from -3.4 degrees Celsius $\left({ }^{\circ} \mathrm{C}\right)$ in January to $25.3{ }^{\circ} \mathrm{C}$ in July, and monthly minimum temperatures ranging from $-17.7^{\circ} \mathrm{C}$ in January to $3.2^{\circ} \mathrm{C}$ in July (Western Regional Climate Center, 2019; period of record 1905-2016). The drainage area is located almost entirely within Yellowstone National Park, the Bridger-Teton National Forest, and the John D. Rockefeller Jr. Memorial Parkway and has minimal anthropogenic effects (Marston and Anderson, 1991). 


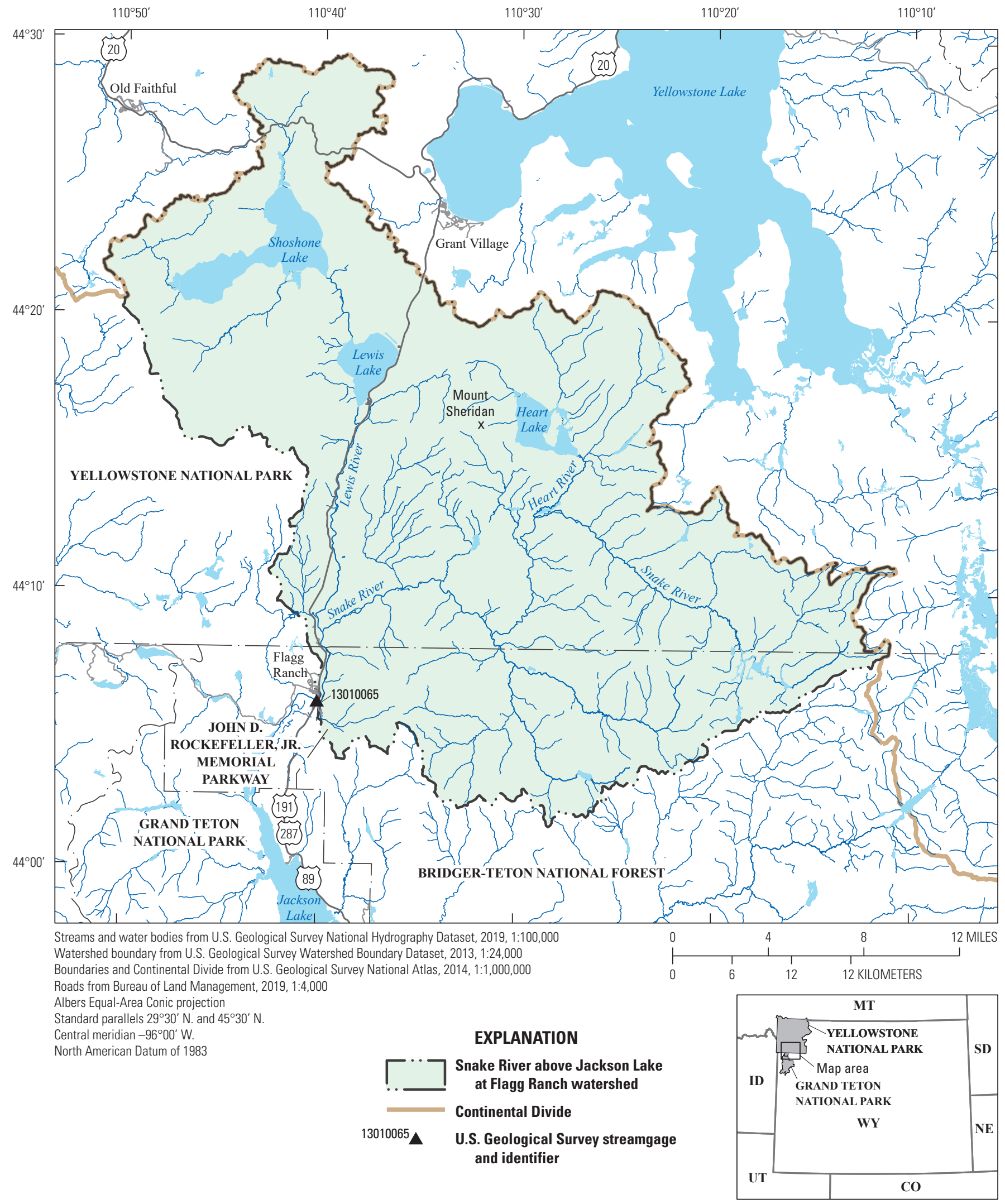

Figure 1. Location and drainage area of U.S. Geological Survey streamgage 13010065, Snake River above Jackson Lake at Flagg Ranch. 


\section{Methods}

Data used for analysis for this project were retrieved from the USGS National Water Information System (USGS, 2019) database for the USGS data and the STORET database (U.S. Environmental Protection Agency, 2020) for NPS-collected data. The sampling agency and the sampling period of record for all constituents evaluated for this study are shown in table 1 . Discharge and water-quality sampling techniques, and descriptions of laboratory analyses for samples collected by the USGS are described in Clark and others (2004) and are briefly described below. NPS water-quality sampling techniques are equivalent to USGS methods for the constituents examined in this study. Descriptions of those methods and laboratory analyses for samples collected by the NPS are available in O'Ney and others (2011) and Levandowski and others (2017).

Field methods used for the USGS discharge measurements and water-quality sampling followed standard methods described in Rantz (1982) and the "National Field Manual for the Collection of Water-Quality Data" (U.S. Geological Survey, variously dated), respectively. Stream properties were measured in the field and included discharge and specific conductance.

The onset of snowmelt runoff was calculated using methods described in Cayan and others (2001). Data from January 1984 to December 2018 at the Snake River at Flagg Ranch were used in the calculations.

Water-quality samples generally were collected using a DH-81 sampler, and depth-integrated samples were collected using equal-width increments or multiple-vertical techniques. Samples collected by the USGS were analyzed for major-ion chemistry, nutrients, and other constituents at the USGS National Water Quality Laboratory in Lakewood, Colorado.

Table 1. Stream properties and chemical constituents for which water samples were analyzed at the U.S. Geological Survey Snake River above Jackson Lake at Flagg Ranch streamgage (13010065).

[USGS, U.S. Geological Survey; NPS, National Park Service; NC, not collected]

\begin{tabular}{llc}
\hline $\begin{array}{c}\text { Stream property and } \\
\text { chemical constituent }\end{array}$ & $\begin{array}{c}\text { Agency } \\
\text { collecting data }\end{array}$ & $\begin{array}{c}\text { Year (or partial } \\
\text { year) data collected }\end{array}$ \\
\hline Continuous discharge & USGS & $1983-2018^{\mathrm{a}}$ \\
Specific conductance & USGS & $1985-2004$ \\
& NPS & $2006-18^{\mathrm{a}}$ \\
Dissolved solids & USGS & $1986-2004$ \\
& NPS & NC \\
\hline
\end{tabular}

aDischarge measurements and water-quality sampling have continued past 2018 but are not included in this report.
The concentration of dissolved solids was calculated as the summation of all dissolved constituents, with primary contributors being major ions (calcium, magnesium, potassium, sodium, carbonate, chloride, fluoride, and sulfate) and nonionic silicon (Clark and others, 2004). Samples collected by the NPS were collected using the same sampler and techniques as the USGS, but those samples were analyzed for many different constituents by different labs during the period of the data collection (O'Ney and others, 2011; Yoder and others, 2016; Levandowski and others, 2017). Dissolved solids were not analyzed or calculated for the NPS samples.

Water-quality samples were collected by both agencies during site visits; however, samples for analysis of dissolved solids were collected regularly only by the USGS. Specific conductance was measured by the USGS (U.S Geological Survey, 2019) and the NPS (O'Ney and others, 2011; Yoder and others, 2016; Levandowski and others, 2017) at each visit.

Statistical methods described below were used to evaluate the data from the two agencies for comparability. Statistical methods were also used to develop the relation between specific conductance and dissolved solids, summarize constituents of interest, and evaluate temporal trends in discharge and dissolved-solids concentration.

Specific conductance data from USGS and NPS were compared to evaluate the validity of combining the two datasets into a single dataset using methods described by Helsel and Hirsch (2002). Specifically, the data from each agency were compared using the interquartile ranges, visual inspection of specific conductance data over time across the transition from USGS to NPS sampling, and Krukal-Wallis tests for differences among datasets (Helsel and Hirsch, 2002). Seasonality of differences was assessed using a comparison of interquartile ranges and Kruskal-Wallis tests (Helsel and Hirsch, 2002).

Because of a lack of dissolved-solids data collected by the NPS, a dissolved-solids record was estimated using NPS-collected specific conductance data, in a manner similar to other studies that have used specific conductance to estimate a variety of water-quality constituents (Clark and Davidson, 2009). Linear regression is a technique for estimating one water-quality variable on the basis of another water-quality variable (Helsel and Hirsch, 2002). Therefore, a linear, least-squares regression model of dissolved solids and specific conductance was developed using 134 samples collected by the USGS, and the model was used to predict a dissolved-solids record from the NPS-collected specific conductance data.

Statistical analyses were used to determine if samples collected in one season differed from another season, or if temporal trends by season could be determined. Seasons were assigned the following months - winter: December, January, February; spring: March, April, May; summer: June, July, August; fall: September, October, November. 
Weighted Regressions on Time, Discharge, and Season (WRTDS) (Hirsch and others, 2010; Choquette and others, 2019) was used to characterize the status, trends, and associated uncertainties in annual dissolved-solids concentrations and loads. The EGRET 3.0 and EGRETci $2.0 \mathrm{R}$ packages were used (Hirsch and De Cicco, 2015, 2018). WRTDS is a multivariate smoothing approach to estimate a time series of "flow normalized" fluxes using water-quality data and an integrated probability distribution of discharge conditions. WRTDS creates a flexible statistical model of concentration throughout the period of record based on measured concentration values. The modeled daily concentration is a function of time, season, and discharge. The observations are weighted based on how similar they are to the estimated value in time, season, and discharge. WRTDS uses "generalized flow normalization" to remove the variability in water-quality conditions that is directly related to the random variations in discharge. This method generates a daily time series of smoothly varying concentrations (or fluxes) by defining the concentration-discharge relationship at a daily scale, and then integrating it over a time-varying probability density function of daily mean discharge for each day of the year (Choquette and others, 2019). Therefore, this method allows for the distinction between trends due to changes in discharge and trends due to changes in the concentration-discharge relationship. The concentration-discharge relationship can vary over time as processes that influence constituent loading to streams, such as land use or waste discharge, change.

Uncertainty of the trend analysis was evaluated through a bootstrap test to determine confidence intervals on concentration and load estimates over time and the calculation of trend likelihood (Hirsch and others, 2015; Hirsch and De Cicco, 2015). Probabilities and a likelihood description of trends and their direction are estimated as part of the uncertainty analysis. The likelihood descriptions follow those described in Hirsch and others (2015). A trend is highly likely if the probability of a trend is greater than or equal to $(\geq) 0.95$ and less than or equal to $(\leq)$ 1.0. A trend is very likely if the probability is $\geq$ to 0.90 and less than $(<) 0.95$. A trend is likely if the probability is $\geq$ to 0.66 and $<0.90$. A trend is about as likely as not if the probability is greater than $(>) 0.33$ and $<0.66$. A trend is unlikely if the probability is $>0.1$ and $\leq 0.33$. A trend is very unlikely if the probability is $<0.05$ and $\geq 0.1$. A trend is highly unlikely if the probability is $\geq 0$ and $\leq 0.05$.

\section{Discharge, Specific Conductance, and Dissolved-Solids Characteristics}

Discharge, specific conductance, and measured and modeled dissolved-solids concentrations during January 1986 to December 2018 were used to describe the characteristics of the Snake River at Flagg Ranch. Statistical analyses were used to determine trends in discharge and dissolved solids during this time period.

\section{Discharge}

Continuous discharge has been collected at the Snake River at Flagg Ranch streamgage since October 1983 (fig. 2). The mean of the daily mean discharge during most of the year was around 10 cubic meters per second $\left(\mathrm{m}^{3} / \mathrm{s}\right)$ and increased annually in response to snowmelt (fig. 3). During 1983-2018, the increase in daily mean discharge in response to snowmelt began between April 7 (2004) and May 14 (1984 and 2010), with a mean date of snowmelt onset occurring on April 26. During 1983-2018, peak discharges occurred between April 30 (1987) and June 24 (2011), with the mean date of peak discharge during 1986-2018 occurring on May 24 (U.S. Geological Survey, 2019). The peak discharge during this time ranged from $82 \mathrm{~m}^{3} / \mathrm{s}$ (1987) to $425 \mathrm{~m}^{3} / \mathrm{s}$ (1996), with a mean peak discharge of $235 \mathrm{~m}^{3} / \mathrm{s}$.

\section{Changes in Discharge, 1986-2018}

Discharge is an important parameter to consider when analyzing water-quality constituents because the quantity of flow in the stream affects the concentration of many water-quality constituents. To understand potential changes over time in dissolved solids, discharge was analyzed between January 1986 and December 2018, which corresponds with the time period when water-quality data were collected.

Mean annual discharge has varied during the study period (fig. 4). Different descriptors of flow, specifically the maximum 1-day daily mean, mean of the daily mean, median of the daily mean, and minimum 7-day mean of the daily mean, are used to describe the dynamics of discharge. The maximum 1-day daily mean describes the magnitude of the highest daily mean flow during that year. The large variation in the maximum 1-day daily mean flow that occurred during the study period, where the highest maximum flows are more than five times larger than the lowest maximum flows, is shown in figure 4 . The mean and median of the daily mean are descriptors of discharge over the entire year, with the mean of daily mean having more variability due to the influence of high flows on mean calculations when compared to the median of the daily mean. The minimum 7-day mean of daily mean describes how low the lowest flows were during a 7-day period of time during the year. In general, all descriptors of discharge indicate that discharge increased from 1986 through 1998 and declined through 2005. After 2005, the median and mean of daily mean increased, the maximum 1-day daily mean continued to decrease, and the minimum 7-day mean of daily mean stayed relatively constant. 


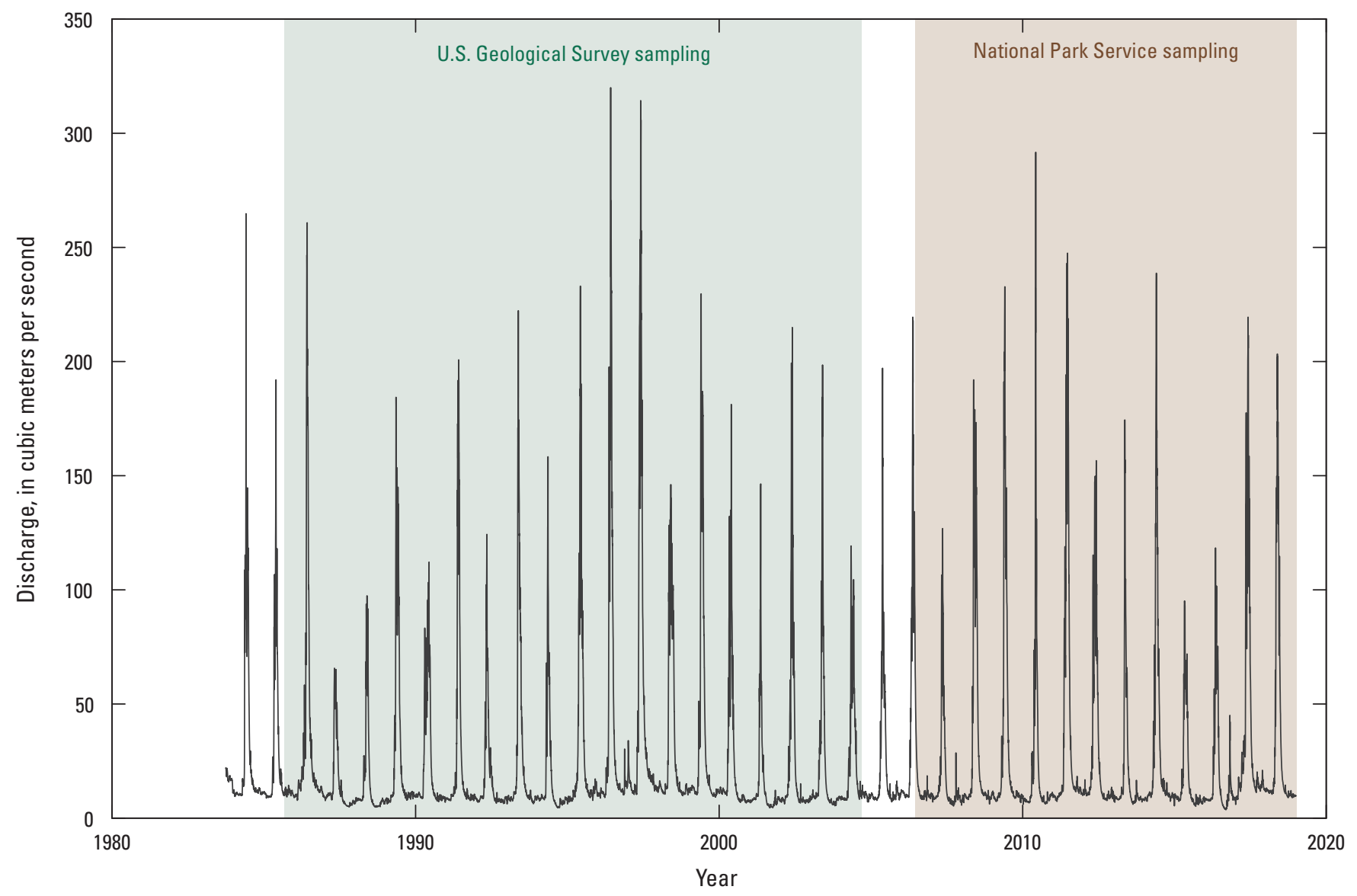

Figure 2. Daily mean discharge at Snake River above Jackson Lake at Flagg Ranch, October 1983-December 2018. 


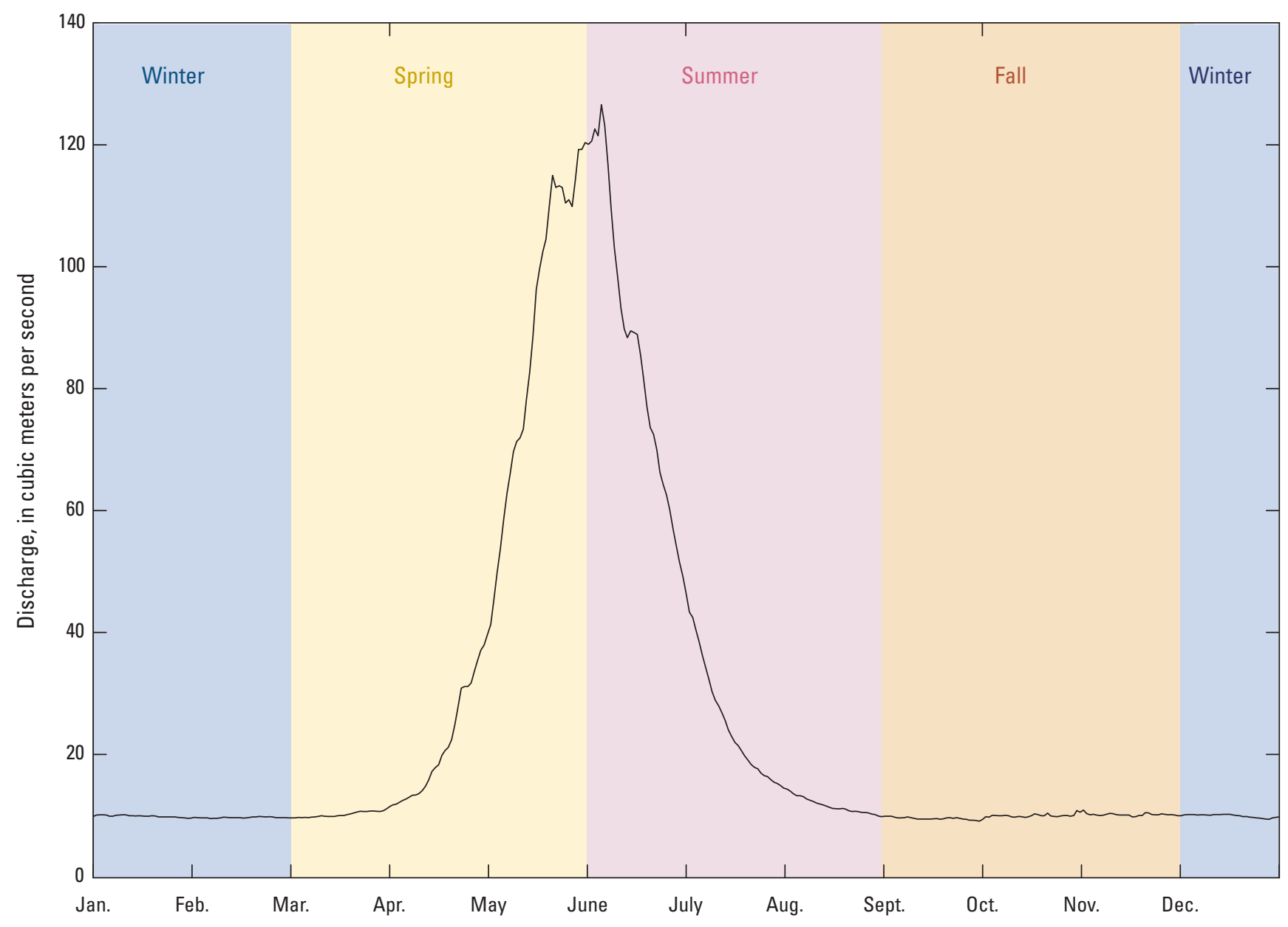

Figure 3. Mean of daily mean discharge, Snake River above Jackson Lake at Flagg Ranch, 1983-2018. 

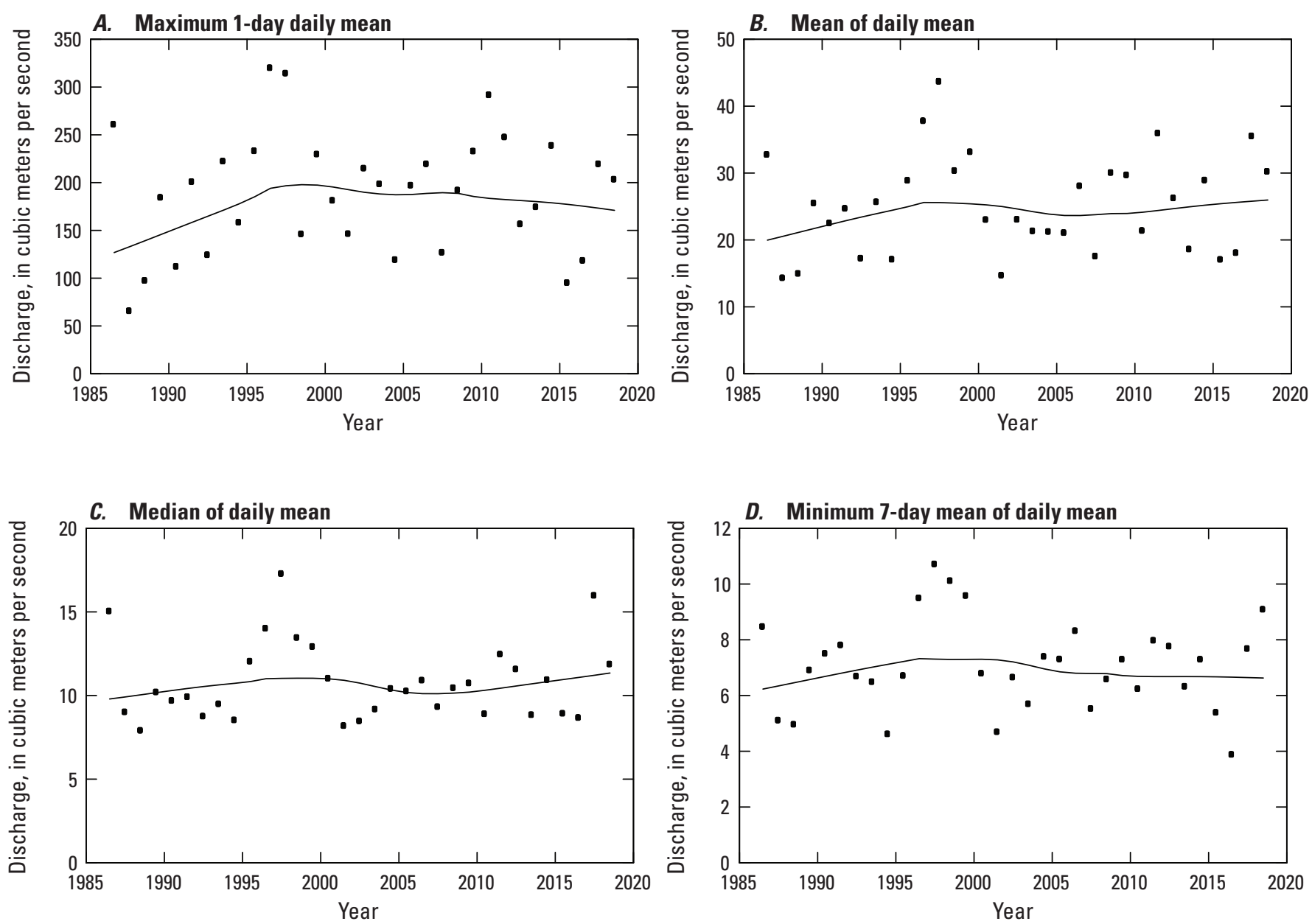

\section{EXPLANATION}

- Average annual discharge

Smoothed estimate of discharge

Figure 4. Plot showing discharge characteristics of Snake River above Jackson Lake at Flagg Ranch streamgage, January 1986December 2018. $A$, Maximum 1-day daily mean. $B$, Mean of daily mean. $C$, Median of daily mean. $D$, Minimum of 7-day daily mean.

\section{Specific Conductance}

Specific conductance data were collected by the USGS and NPS during the period of study. To determine if the datasets could be combined, visual inspection of graphs and statistical analyses, including a comparison of interquartile ranges (IQRs) and Kruskal-Wallis tests, were conducted (Helsel and Hirsch, 2002). Seasonality of differences was assessed using similar statistical tests. Specific conductance data IQRs are similar, and rapid or large changes in values do not occur during the period of transition between USGS and NPS sampling (fig. 5). The USGS specific conductance IQR is between 186 and 295 microsiemens per centimeter at $25^{\circ} \mathrm{C}$ and the NPS specific conductance IQR is between 154 and 253 microsiemens per centimeter at $25^{\circ} \mathrm{C}$. The individual
USGS and NPS specific conductance datasets are statistically different (Kruskal-Wallis rank sum test chi squares $=7.4967$, degree of freedom $=1, p$-value $=0.006181$ ); however, the statistical differences between specific conductance data for each agency may be due to differences in time of sampling or changes in the actual specific conductance in the stream.

The NPS and USGS datasets are not statistically different in the spring, summer, or fall. For specific conductance data, spring, summer, and fall Kruskal-Wallis rank sum test chi squares were 2.3, 0.06, and 3.7; degrees of freedom were 1; and $p$-values were all greater than 0.01 . These data suggest that these overall differences could be driven by the lack of wintertime NPS sampling, which excludes higher specific conductance, lower discharge data. 
$\boldsymbol{A}$

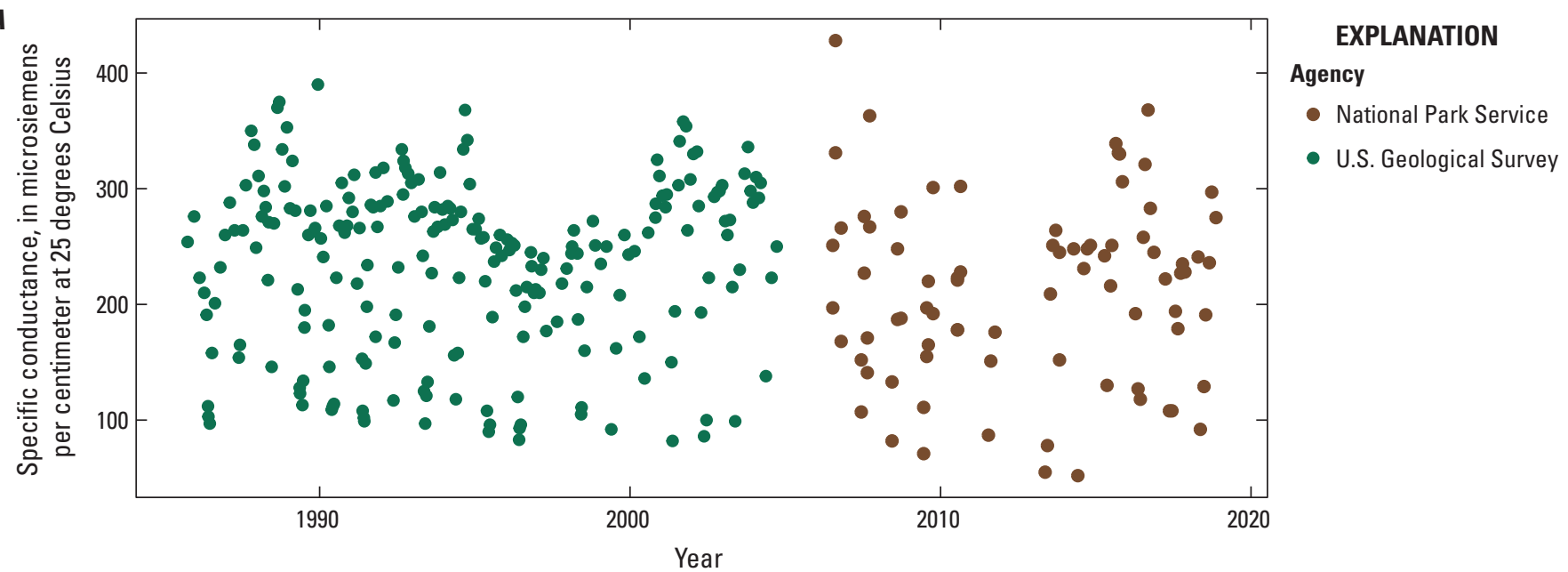

B

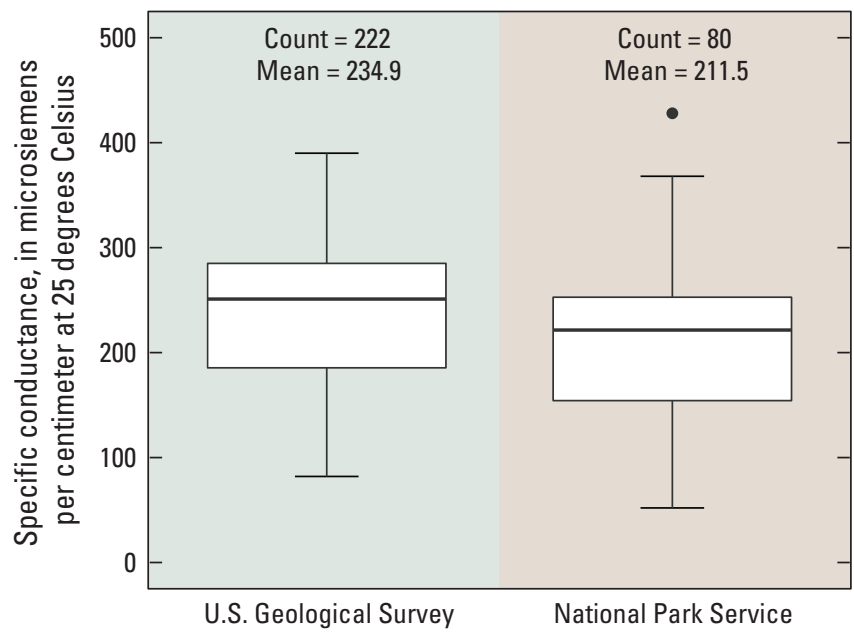

\section{EXPLANATION}

- Individual observation above 95th percentile

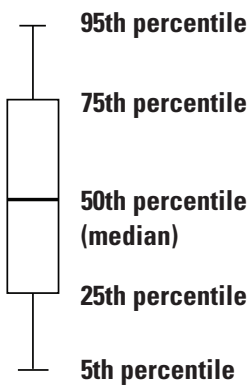

Figure 5. Plot showing measurement of specific conductance at Snake River above Jackson Lake at Flagg Ranch streamgage. $A$, Specific conductance measured over time by agency. $B$, Specific conductance measurement distribution by agency.

\section{Dissolved Solids}

Because the dissolved-solids parameter is useful for water managers, it is often calculated from specific conductance using a linear regression model when dissolved-solids data are unavailable (Clark and Davidson, 2009). For this study, combining data collected by the USGS and NPS provided a longer, more complete dataset of dissolved-solids concentration data.

A linear, least-squares regression model of dissolved solids and specific conductance was developed using 134 samples collected by the USGS and produced the following equation:

$$
D S=0.668(S C)+1.34
$$

where

$D S \quad$ is the dissolved-solids concentration, in milligrams per liter; and
$S C$ is the specific conductance, in microsiemens per centimeter at 25 degrees Celsius, (coefficient of determination $=0.98, p$-value $<2.2 \mathrm{e}-16)$.

This statistically significant regression was used to calculate dissolved-solids concentration from specific conductance data collected by the NPS and the USGS when dissolved-solids data were unavailable.

\section{Dissolved-Solids Characteristics}

From 1986 through 2018 the number of dissolved-solids values measured or calculated (eq. 1) varied from 2 to 16 . No samples were collected in 2005 and 2012 (fig. 6). The total number of samples decreased over time, and after 2004, when the NPS began the water-quality sampling, winter sampling ceased. 


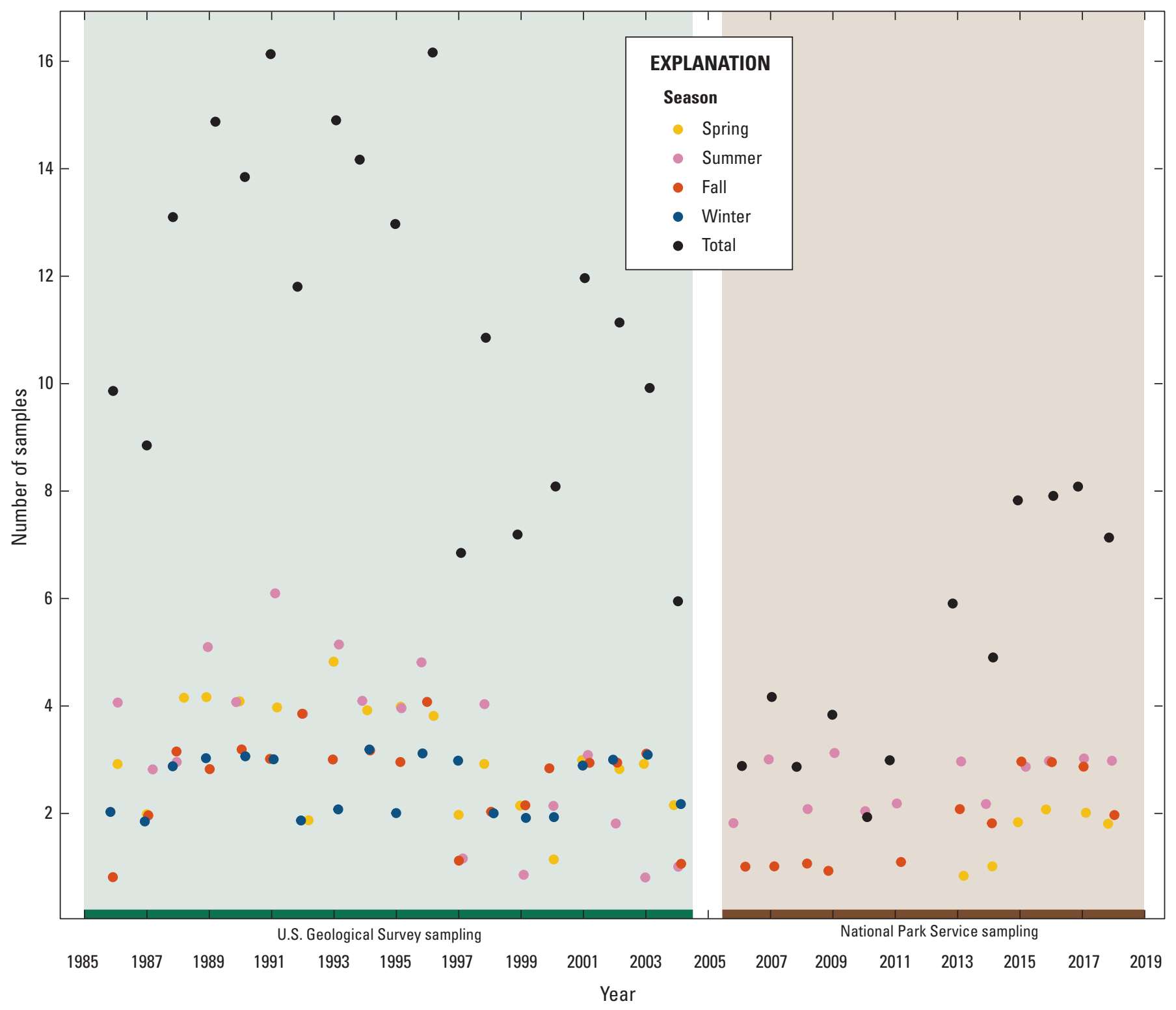

Figure 6. Number of water-quality samples collected over time by season at Snake River above Jackson Lake at Flagg Ranch.

Concentrations of dissolved solids over time and by season are shown in figure 7. Samples collected in the fall and winter have higher concentrations than samples collected in spring and summer (fig. 8). Mean dissolved-solids concentrations in fall and winter are approximately 188 milligrams per liter $(\mathrm{mg} / \mathrm{L})$, whereas the mean concentrations in the spring and summer are approximately $130 \mathrm{mg} / \mathrm{L}$. This lower mean dissolved-solids concentration in the spring and summer is generally attributed to dilution by snowmelt during the higher flows of those seasons (fig. 3).

Dissolved-solids concentrations and discharge typically have an inverse relation for streams originating from mountainous areas because the concentrated base flow generally is diluted during increased discharge resulting from precipitation and snowmelt (Clark and others, 2004). The relation between concentration and discharge is plotted on a logarithmic scale for the discharge data to yield a log-linear relationship between concentration and discharge. This relationship is generally similar, regardless of the season when data were collected (fig. 9). Seasonal and annual changes to this relationship are discussed below.

During most of the year, discharge is near the base-flow value of $10 \mathrm{~m}^{3} / \mathrm{s}$, and the sampling bias towards lower flows is shown in figure 9. Fewer data have been collected at discharges greater than about $25 \mathrm{~m}^{3} / \mathrm{s}$, in part because of the lower percentage of time that flows are greater than $25 \mathrm{~m}^{3} / \mathrm{s}$. As shown in figure 9, the relation between concentration and discharge is more variable at higher flows (greater than 50 $\mathrm{m}^{3} / \mathrm{s}$ ) and tends to have more outliers. 


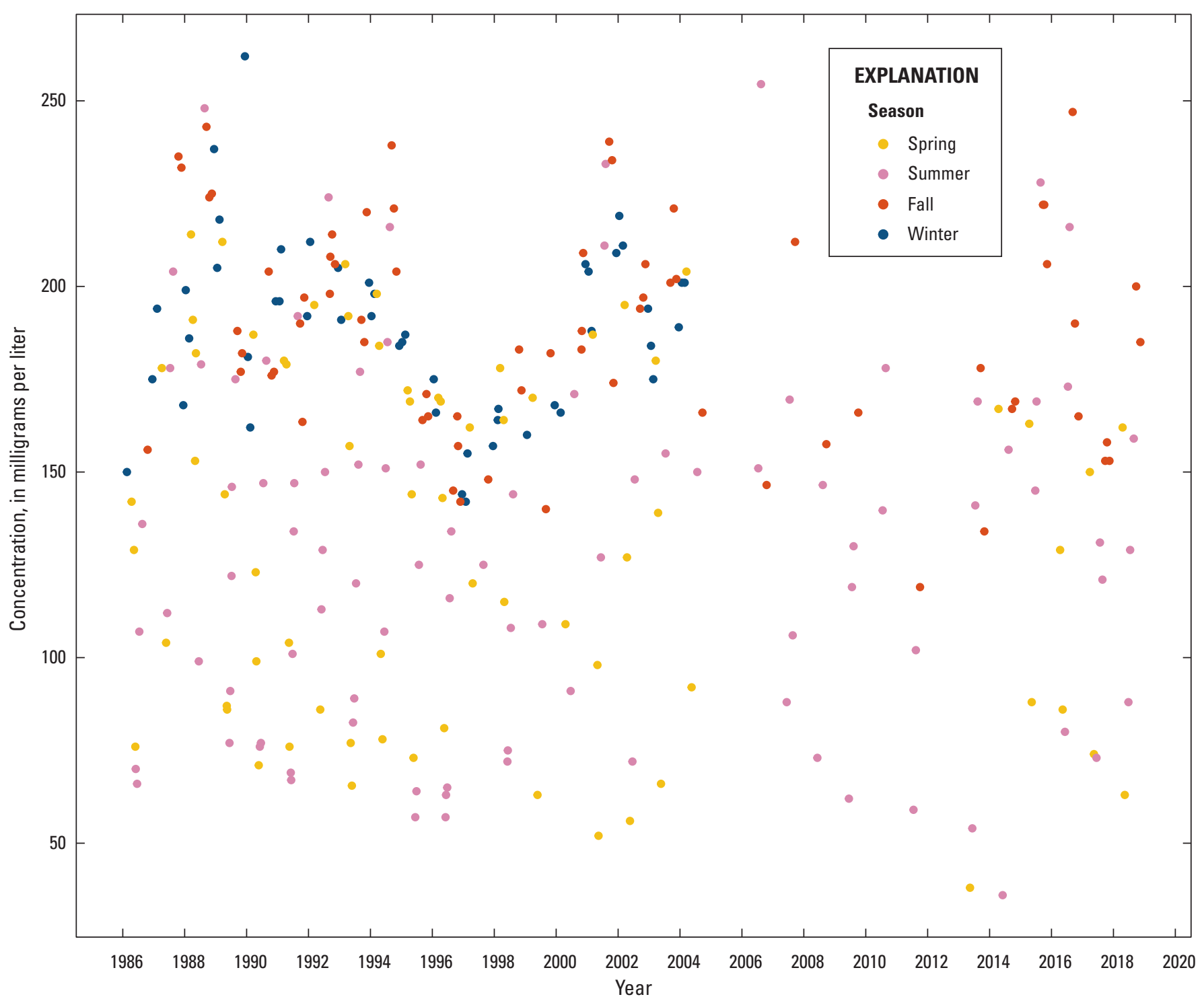

Figure 7. Dissolved-solids concentration over time identified by season at Snake River above Jackson Lake at Flagg Ranch. 


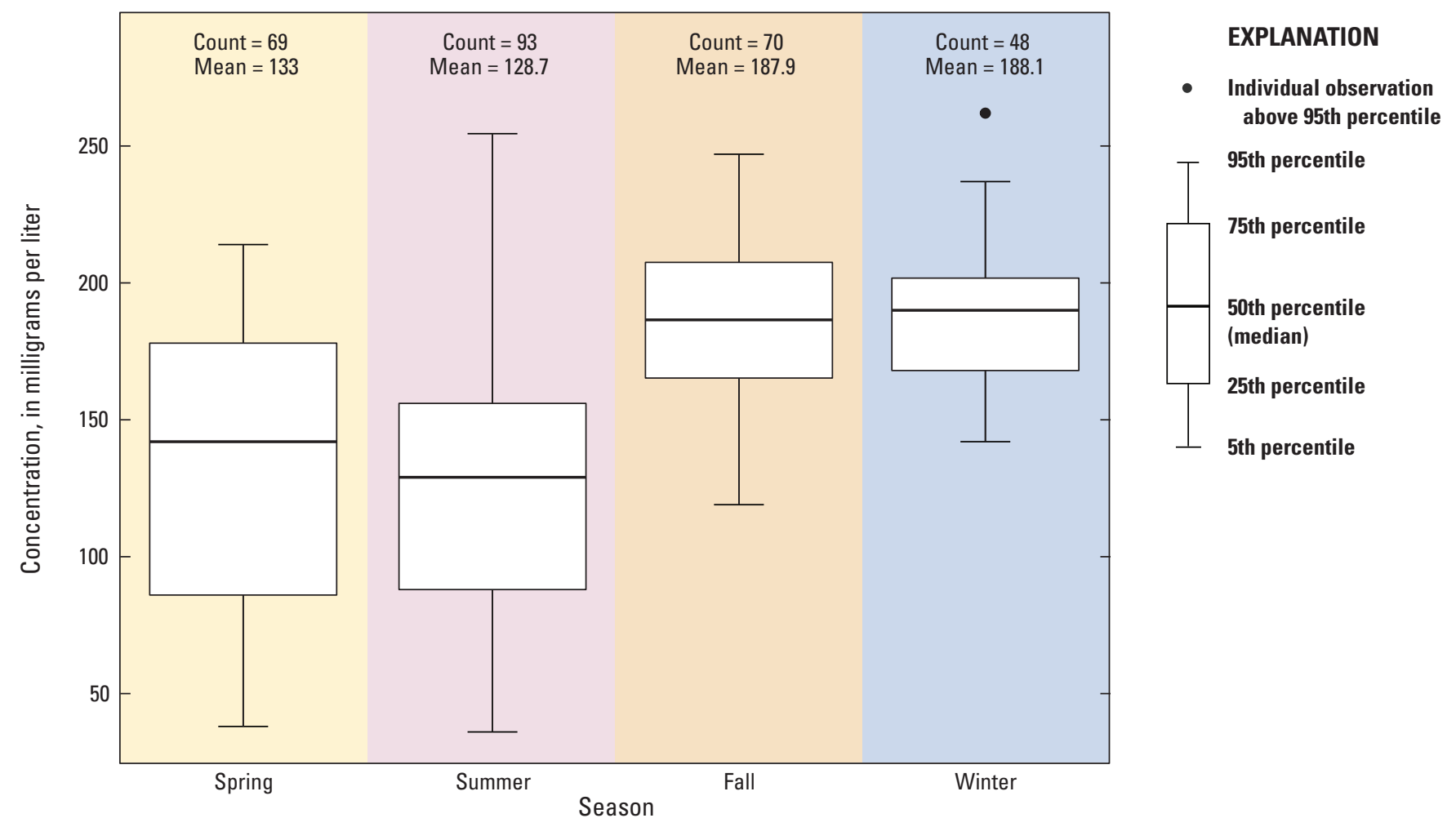

Figure 8. Dissolved-solids concentration distribution by season at Snake River above Jackson Lake at Flagg Ranch. 


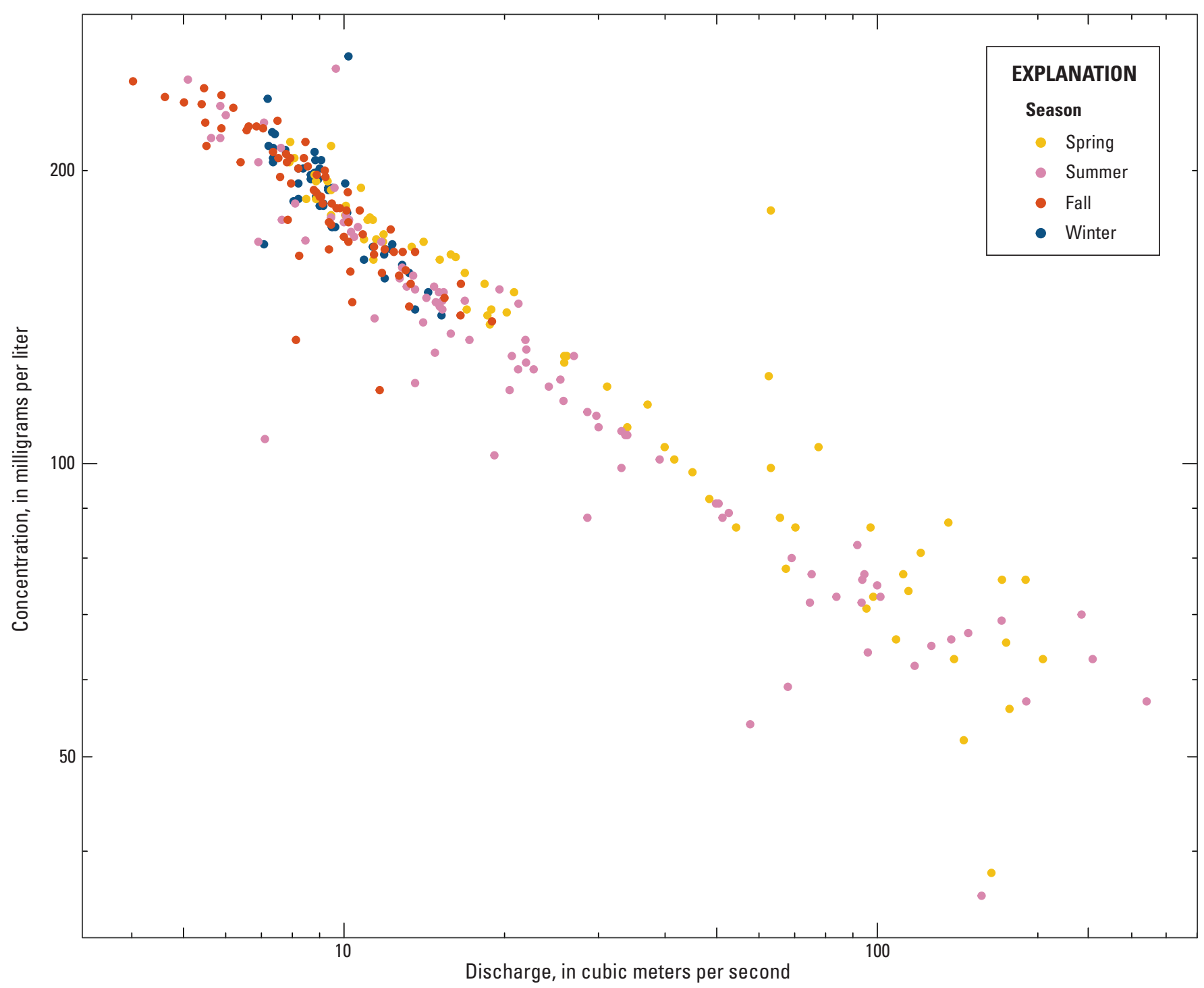

Figure 9. Total dissolved-solids concentration compared to discharge by season at Snake River above Jackson Lake at Flagg Ranch.

\section{Dissolved-Solids Trends, 1986-2018}

The WRTDS method was used to normalize the concentrations and flux (load) and evaluate trends in dissolved solids over time. Model performance was evaluated through the flux bias statistic and visual inspection of diagnostic plots. The flux bias statistic, which represents the model's ability to predict the observed flux, compares the sum of the estimated fluxes on all sampled days to the sum of observed fluxes on all sampled days. A value near zero indicates that the model is nearly unbiased. A positive value indicates positive bias, where model flux estimates are greater than observed fluxes; and a negative value indicates negative bias, where model flux estimates are less than observed fluxes. Values between -0.1 and +0.1 indicate that bias estimates in the long-term mean flux are likely less than 10 percent. The flux bias statistic for data examined in this study is 0.00131 , indicating low bias. Plots useful in assessing model fit are shown in figure 10. The general symmetry and lack of curvature in model residuals versus estimated concentration (fig. $10 \mathrm{~A}$ ) and model residuals versus discharge (fig. 10B) indicate good model fit. The observed concentrations versus estimated concentrations for the same day (fig. 10C) and the observed versus estimated flux values (fig. 10D) generally falling along a 1:1 line also indicate good model fit. The flux bias statistic and diagnostic plots indicate overall good model fit.

Dissolved-solids loads are difficult to measure directly and are instead computed using dissolved-solids concentration and discharge data. As such, dissolved-solids loads are affected by dissolved-solids concentration and discharge. Dissolved-solids concentrations and loads at the Snake River at Flagg Ranch have varied over time (fig. 11). Trend results indicate that from 1986 to 2018 an upward trend in concentration is likely (probability is 0.71 ) and a downward trend in load is highly likely (probability is 0.98 ). 

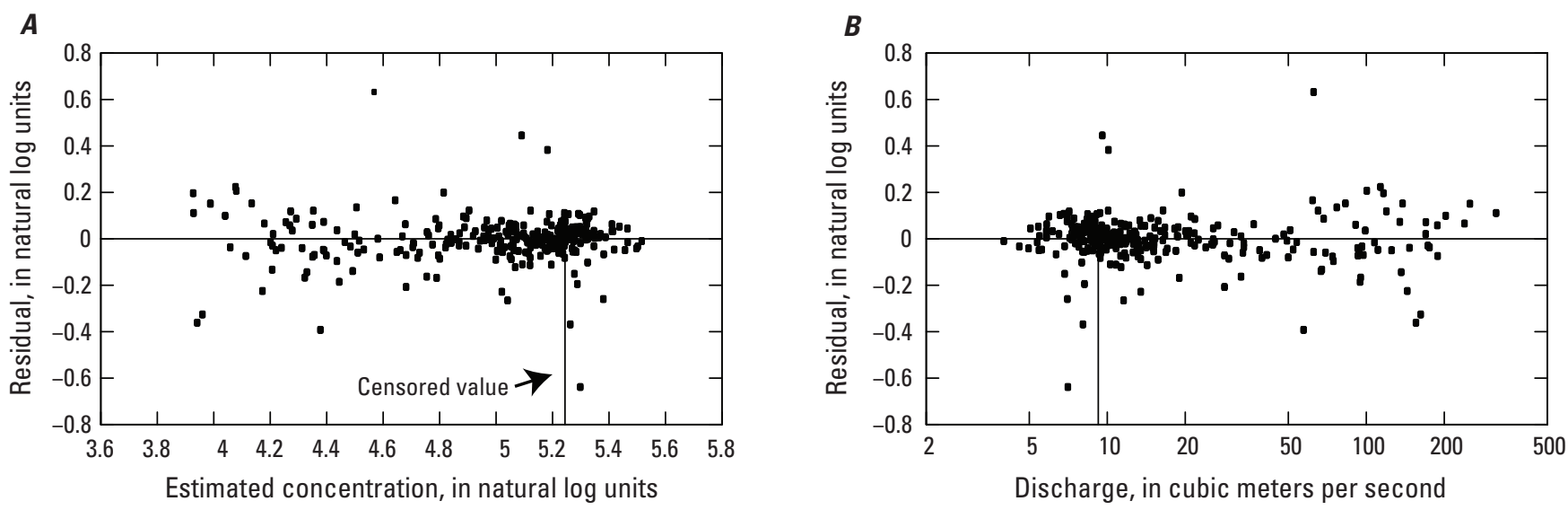

C

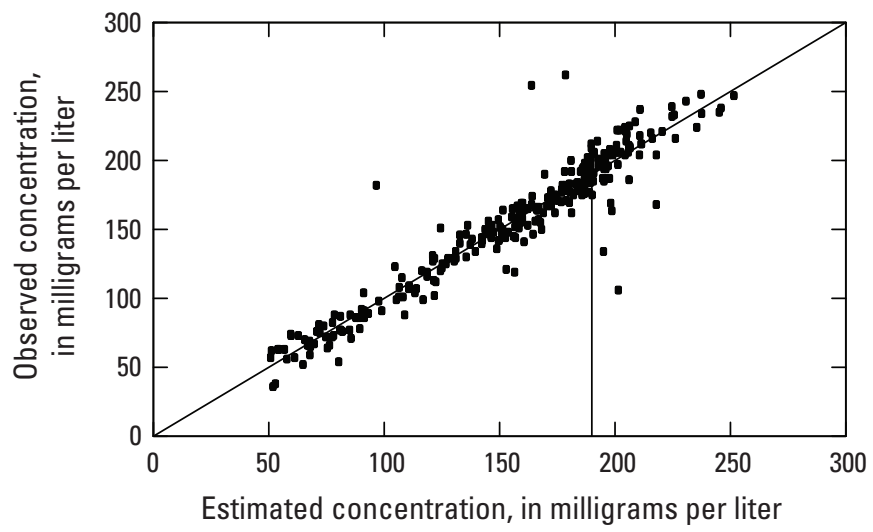

D

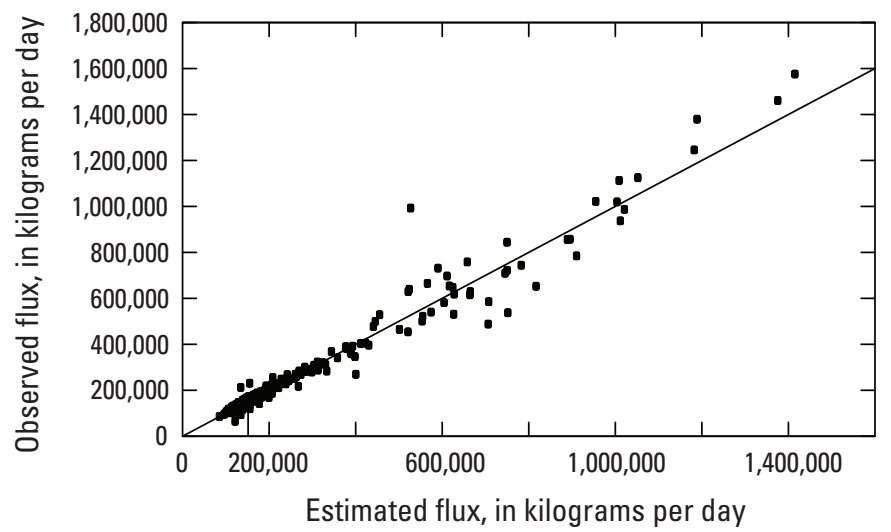

Figure 10. Plot showing results of Weighted Regressions on Time, Discharge, and Season model analyses at Snake River above Jackson Lake at Flagg Ranch. $A$, Residual versus estimated concentration. $B$, Residual versus discharge. $C$, Observed versus estimates concentration. $D$, Observed versus estimated flux.

Comparing 1986 to 2018, dissolved-solids concentration is estimated to have increased by $2.25 \mathrm{mg} / \mathrm{L}$ (1.4 percent). During that same period, the dissolved-solids load is estimated to have decreased 11.8 million kilograms per year (12-percent decrease). This dissolved-solids load decrease is consistent with the estimated decrease in annual mean of daily mean discharge of 8 percent. Ten percent of that total change in dissolved-solids load is related to a change in the concentration-discharge relationship, whereas 2 percent is related to changes in discharge. The difference in the percent attributed to changes in the concentration-discharge relationship and changes in discharge indicates that the change in the concentration-discharge relationship indicates that the decreased load is related less to changes in discharge and more to landscape-level processes that are affecting the concentration-discharge relationship. Trend results for data from Spring through Fall (excluding Winter data) show decreases in concentration of $3.12 \mathrm{mg} / \mathrm{L} \mathrm{(-2} \mathrm{percent)} \mathrm{and} \mathrm{load}$ of 16.3 million $\mathrm{kg} /$ year (-15 percent), with a majority of the change attributed to changes in the concentration-discharge relationship (-13 percent of the total 115 percent). The differences in concentration trend direction for tests using all four seasons compared to only three seasons highlights the necessity for winter dissolved solids data in evaluating trends and points to landscape-scale processes as the driver. Although determining what process(es) caused the trends identified here is outside the scope of the study, many factors, including, but not limited to, climate, land use and land-use practices, and vegetation can affect dissolved-solids loading to streams. 
$\boldsymbol{A}$

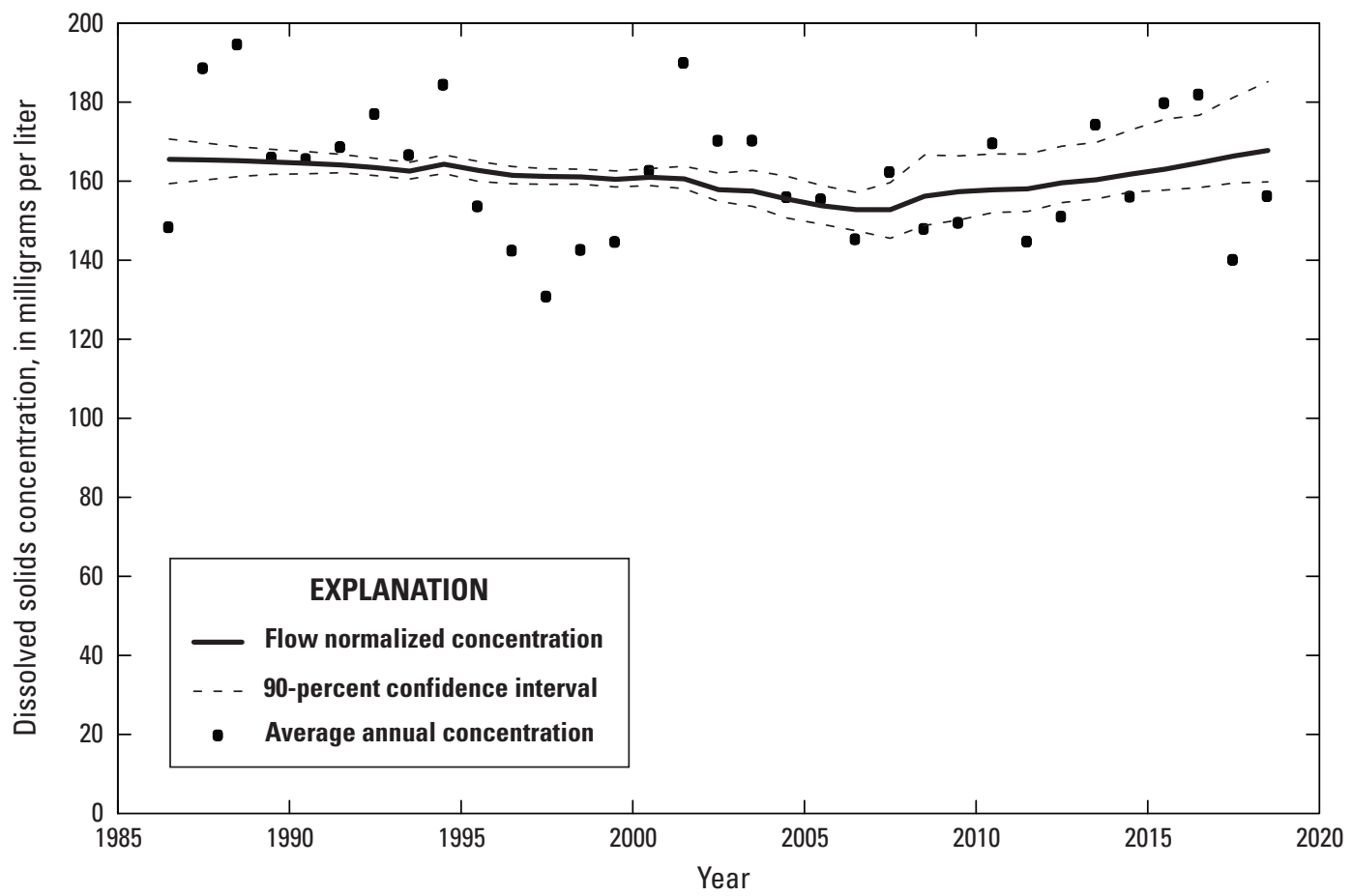

B

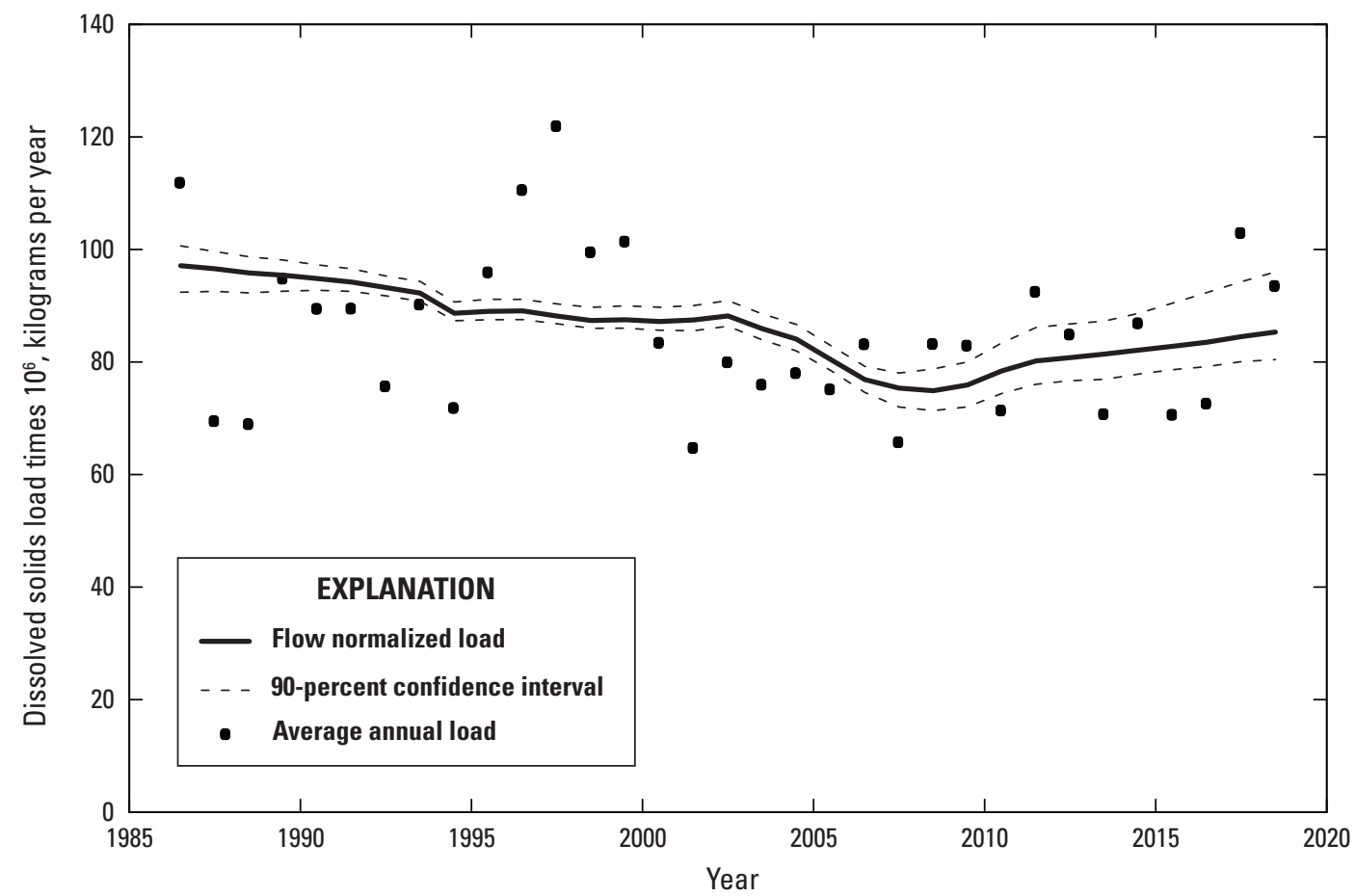

Figure 11. Estimated total dissolved-solids over time at Snake River above Jackson Lake at Flagg Ranch. $A$, Concentrations. $B$, Loads. 
The WRTDS analysis provides insights into the modeled relationship between concentration and discharge over time. Temporal changes in the modeled concentration-discharge relationship are shown in figure 12, including the modeled concentration-discharge relationship at three dates in each season from 1987, 2002, and 2017. The dates are meant to represent key parts of each season and these years are meant to represent the beginning, middle, and end of the sampling period of record. The modeled relationship changed most during the winter (fig. 12A) and early spring months. The relationship became more similar across the years in spring, coincident with the onset of snowmelt (fig. 12B) and has stayed consistent during summer months (fig 12C). The relationship began to differ over the years in the fall again, although only slightly (fig. 12D). In winter, the estimated concentration increased at low discharge, particularly between 2002 and 2017, and decreased at high discharge, particularly between 1987 and 2002. Some of the winter changes were possibly related to changes in sampling timing associated with the transition from USGS to NPS sampling and reduction in winter sample collection. During the spring, summer, and fall, the concentration decreased over time at high discharge and stayed relatively consistent over time at low flows. A decrease in concentration for a given discharge will result in a decrease in load. These changes in the concentration-discharge relationship, and the decreases in particular, contribute to the decreased dissolved-solids load over time.
A

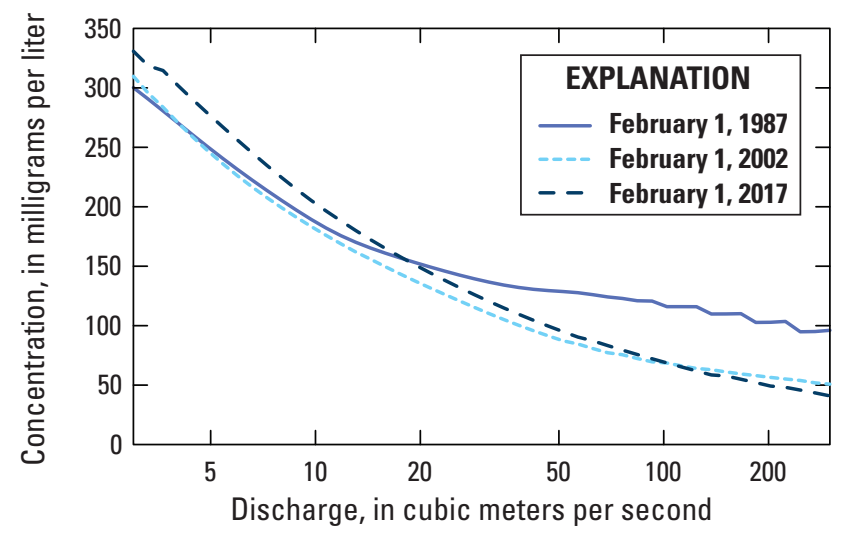

C

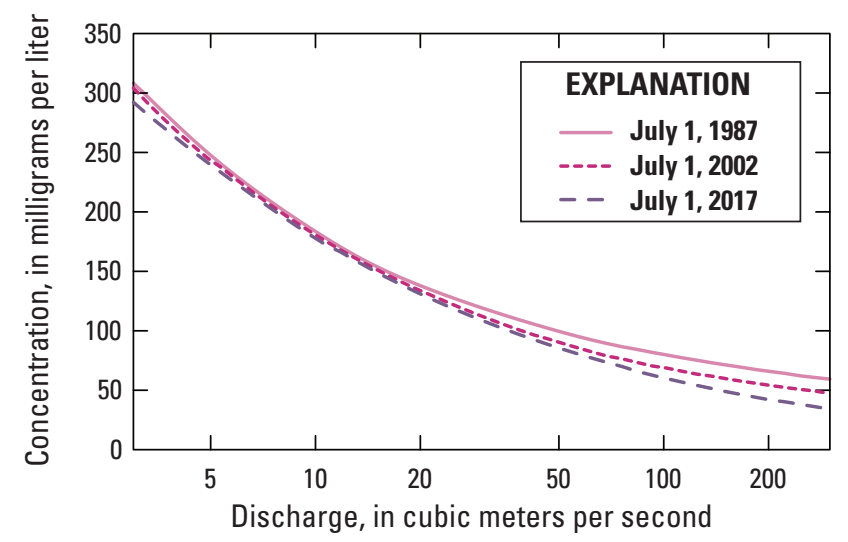

B

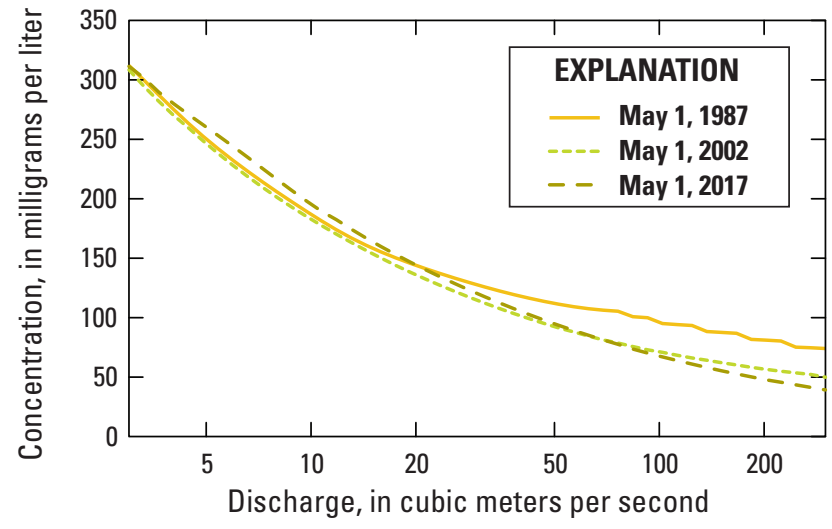

D

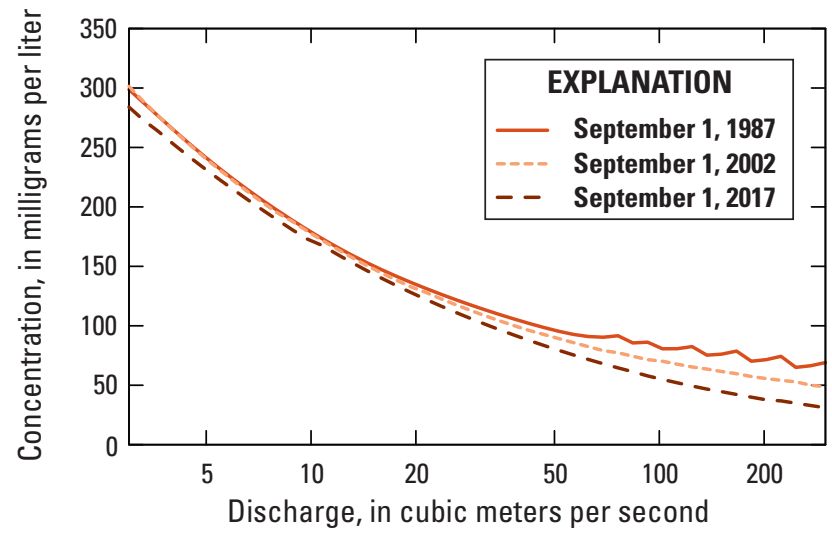

Figure 12. Modeled concentration-discharge relationship over time at Snake River above Jackson Lake at Flagg Ranch. $A$, February. $B$, May. $C$, July. $D$, September. 


\section{Dissolved-Solids Sampling Frequency and the Potential Effects on Data Analysis}

As noted above, the data collected by the USGS and NPS are generally comparable with regards to sampling and analytical methods. Although the sampling frequency between the two agencies has varied, statistical analysis of the data collected between 1986 and 2018, indicated it is appropriate to use data collected by both agencies as one dataset for trend analyses.

The current NPS sampling schedule, however, is creating a dataset biased towards lower concentration dissolved-solids data by sampling during April through November. The changes in dissolved-solids concentration and load that occurred during the period prior to NPS sampling are not subject to this seasonal influence. However, because of the importance of low flow (winter season) and high flow (late spring), it is likely that an April through November sampling regime may affect the ability to characterize the concentration-discharge relationship, detect trends, or determine their seasonality. Collection of winter data in particular is important based on the finding that the changes in the modeled concentration-discharge relationship over time have been most pronounced during the winter (February) months when fewer data are available to constrain the model.

Because the discharge and dissolved-solids concentrations at the Snake River at Flagg Ranch streamgage represent activities upstream in the entire basin and the site is an integrator of changes on the landscape over a large area, small changes, which are typical responses to changes in climate or landscape-scale processes, may be difficult to detect. Therefore, without year-round data collection, there is a potential to miss changes that might be important to ecological processes.

\section{Summary}

The headwaters of the Snake River are located in the mountains of northwestern Wyoming, primarily on lands administered by National Park Service (NPS) and the Bridger-Teton National Forest. The high-quality waters currently found in Grand Teton National Park are recognized as an important resource by the NPS, and maintaining this quality of water is a priority of the NPS. In 2006, the NPS established a water-resources monitoring program to monitor the water quality in surface water in the area, and as part of that program, water-quality data were collected at the Snake River above Jackson Lake at Flagg Ranch (streamgage 13010065; referred to as Snake River at Flagg Ranch), a site where the U.S. Geological Survey previously sampled water quality from 1986 through 2004. In order to better understand the overall water-quality characteristics of the
Snake River and determine if changes are occurring over time, the USGS, in cooperation with the NPS, evaluated and used the entire dataset to analyze discharge, specific conductance, and dissolved-solids concentrations at the Snake River at Flagg Ranch.

Discharge was analyzed for the period between January 1986 and December 2018, which corresponds with the time period when water-quality data were collected. Mean annual discharge has varied during this time, with high, low, mean, and median flows generally increasing from 1986 through 1998, decreasing through 2005, and then a general increase for mean and median flows through 2018.

Combining water-quality (dissolved solids, either analyzed or calculated) data collected by the USGS and NPS provides a longer, more complete dataset for analyses. Combining the data is justified as the interquartile ranges of specific conductance collected by both agencies are similar, and rapid or large changes in concentration do not occur over the period of transition between USGS and NPS sampling. The individual datasets are statistically different; however this may be due to differences in sampling timing or to changes in the actual concentration in the stream. The datasets are not statistically different in the spring, summer, or fall, indicating that these overall differences could be driven by the lack of wintertime NPS sampling, which excludes higher-concentration, lower-discharge data (assuming that the winter concentration is constant over time).

The concentrations of dissolved solids over time are identified by season and show that samples collected in the fall and winter have higher concentrations than samples collected in spring and summer. Specifically, the mean dissolved-solids concentrations in fall and winter are around $188 \mathrm{mg} / \mathrm{L}$, whereas, the mean concentrations are around $130 \mathrm{mg} / \mathrm{L}$ in spring and summer. The lower spring and summer concentrations are generally attributed to the dilution of spring and summer samples by snowmelt during the high-flow period of the year.

Trend analyses of dissolved-solids concentrations and loads indicate that from 1986 to 2018 an upward trend in concentration is likely, but a downward trend in load is highly likely. Comparing 1986 to 2018, dissolved-solids concentration is estimated to have increased by $2.25 \mathrm{mg} / \mathrm{L}$ (1.4 percent). Over that same period, the load is estimated to have decreased 11.8 million kilograms per year (12 percent decrease). This is consistent with the estimated decrease in annual mean of daily mean discharge. Ten percent of that total change in dissolved solids load is related to a change in the concentration-discharge relationship while 2 percent is related to changes in discharge. This difference indicates that the decreased load is related less to changes in discharge and more to a landscape level process that is affecting the concentration-discharge relationship. The concentration-discharge relationship has changed over time in each season, with general decreases observed. 
As noted above, the data collected by the USGS and NPS are generally comparable with regards to sampling and analytical methods and data collected by both agencies were used as one dataset for trend analyses. The current NPS sampling schedule, however, is creating a dataset biased towards lower concentration total dissolved-solids data (which occurs during higher spring and summer flows) by not sampling during the winter months (December, January, and February). For the period of time from 1986 to 2018, the percentage of NPS samples is small enough that the effect on trends is expected to be minimal. Because of the importance of low flow data (winter season), it is likely that an April through November sampling regime may affect the ability to detect trends or determine seasonality. Collection of winter data in particular is important based on the findings that the changes in the concentration-discharge relationship over time that have been most pronounced during the winter (February) months.

\section{References Cited}

Cayan, D.R., Kammerdiener, S.A., Dettinger, M.D., Caprio, J.M., and Peterson, D.H., 2001, Changes in the Onset of Spring in the Western United States: Bulletin of the American Meteorological Society, v. 82, no. 3, p. 399-415. [Also available at https://doi.org/10.1175/15200477(2001)082<0399:CITOOS>2.3.CO;2.]

Clark, M.L., and Davidson, S.L., 2009, Specific conductance and dissolved-solids characteristics for the Green River and Muddy Creek, Wyoming, water years 1999-2008: U.S. Geological Survey Scientific Investigations Report 2009-5068, 18 p., accessed March 28, 2020, at https://pubs.usgs.gov/sir/2009/5168/.

Clark, M.L., Sadler, W.J., and O’Ney, S.E., 2004, Water-quality characteristics of the Snake River and five tributaries in the upper Snake River Basin, Grand Teton National Park, Wyoming, 1998-2002: U.S. Geological Survey Scientific Investigations Report 2004-5017, 41 p., accessed November 28, 2019, at https://pubs.usgs.gov/sir/2004/5017/.

Choquette, A.F., Hirsch, R.M., Murphy, J.C., Johnson, L.T., and Confesor, R.B., Jr., 2019, Tracking changes in nutrient delivery to western Lake Erie-Approaches to compensate for variability and trends in streamflow: Journal of Great Lakes Research, v. 45, no. 1, p. 21-39. [Also available at https://doi.org/10.1016/j.jglr.2018.11.012.]

Helsel, D.R., and Hirsch, R.M., 2002, Statistical methods in water resources: U.S. Geological Survey Techniques of Water-Resources Investigations, book 4, chap. A3, 524 p.
Hirsch, R.M., Moyer, D.L., and Archfield, S.A., 2010, Weighted regressions on time, discharge, and season (WRTDS), with an application to Chesapeake Bay river inputs: Journal of the American Water Resources Association, v. 46, no. 5, p. $857-880$, accessed January 2020 at https://onlinelibrary. wiley.com/doi/full/10.1111/j.1752-1688.2010.00482.x.

Hirsch, R.M., Archfield, S.A., and De Cicco, L.A., 2015, A bootstrap method for estimating uncertainty of water quality trends: Environmental Modelling \& Software, v. 73, p. 148-166. [Also available at https://doi.org/10.1016/ j.envsoft.2015.07.017.]

Hirsch, R.M., and De Cicco, L., 2015, User guide to Exploration and Graphics for RivEr Trends (EGRET) and dataRetrieval - R packages for hydrologic data: U.S. Geological Survey Techniques and Methods, book 4, chap. A10, 93 p. [Also available at https://doi.org/10.3133/tm4A10.]

Hirsch, R.M., and De Cicco, L., 2018, Guide to EGRET 3.0 enhancements. Retrieved from EGRET 3.0.3: accessed Januray 2020 at http://usgs-r.github.io/EGRET/articles/ Enhancements.html.

Levandowski, M., Ray, A., Mellander, K., and Whaley, C., 2017, Water quality summary for the Snake River and alpine lakes in Grand Teton National Park and John D. Rockefeller, Jr. Memorial Parkway—Preliminary analysis of 2015 data: Fort Collins, Colorado, National Park Service, Natural Resource Report NPS/GRYN/ NRR—2017/1510, 36 p.

Marston, R.A., and Anderson, J.E., 1991, Watersheds and vegetation of the Greater Yellowstone Ecosystem: Conservation Biology, v. 5, no. 3, p. 338-346. [Also available at https://doi.org/10.1111/j.15231739.1991.tb00147.x.]

O’Ney, S.E., Arnold, J., Bromley, C., Hershberger, K., and Sigler, W.A., 2011, Greater Yellowstone Network water quality monitoring annual report—January 2009December 2009: Fort Collins, Colorado, National Park Service, Natural Resource Report NPS/GRYN/ NRR - 2017/1510, 33 p., accessed January 18, 2020, at https://irma.nps.gov/DataStore/DownloadFile/436356.

Rantz, S.E., 1982, Measurement and computation of streamflow: U.S. Geological Survey Water-Supply Paper 2175, v. 1-2, $631 \mathrm{p}$.

U.S. Environmental Protection Agency, 2020, Water quality data (WQX): accessed January 19, 2020, at https://www.epa.gov/waterdata/water-quality-data-wqx. 
U.S. Geological Survey, variously dated, National field manual for the collection of water-quality data: U.S. Geological Survey Techniques of Water-Resources Investigations, book 9, chaps. A1-A10, accessed November 28, 2019, at https://www.usgs.gov/mission-areas/water-resources/ science/national-field-manual-collection-water-qualitydata-nfm.

U.S. Geological Survey, 2019, USGS 13010065 SNAKE RIVER AB JACKSON LAKE AT FLAGG RANCH WY, in USGS water data for the Nation: U.S. Geological Survey National Water Information System database, accessed September 13, 2019, at https://doi.org/10.5066/F7P55KJN. [Site information directly accessible at https://waterdata.usgs.gov/wy/nwis/inventory/?site_no= 13010065\&agency_cd=USGS.]

Western Regional Climate Center, 2019, Wyoming climate summaries: Reno, Desert Research Institute, Western Regional Climate Center, digital data, accessed December 3, 2019, at https://wrcc.dri.edu/cgi-bin/cliMAIN.pl?wy8315.
Wyoming Department of Environmental Quality, 2013, Wyoming surface water classification list: Wyoming Department of Environmental Quality, Water Quality Division, Surface Water Standards, 525 p., accessed January 10, 2020, at http://deq.wyoming.gov/media/ attachments/Water\%20Quality/Surface $\% 20$ Water $\% 20$ Quality\%20Standards/Guidance\%20Documents/20130726_wqd-wpp-surface-water-standards_WyomingSurface-Water-Classification-List.pdf.

Yoder, A., Ray, A., Mellander, K., Whaley, C., and Roy, R., 2016. Water quality summary for the Snake River and alpine lakes in Grand Teton National Park and the John D. Rockefeller, Jr. Memorial Parkway—Preliminary analysis of 2013 data: Fort Collins, Colorado, National Park Service, Natural Resource Report NPS/GRYN/ NRR—2016/1228, 36 p. 

For more information about this publication, contact:

Director, Wyomng-Montana Water Science Center U.S. Geological Survey

3162 Boseman Avenue

Helena, MT 59601

406-457-5900

https://www.usgs.gov/centers/wy-mt-water

and

Director, Utah Water Science Center

U.S. Geological Survey

2329 West Orton Circle

Salt Lake City, Utah 84119-2047

801-908-5000

https://ut.water.usgs.gov

Publishing support provided by the Rolla and Sacramento Publishing Service Centers 
